summer planting of potatoes, the stubble sowing of winter wheat in Siberia, the cluster planting of trees and attempts to breed cows with high butter-fat by hybridization with Jerseys by Lysenkoist principles. From this it appears that incalculable harm was inflicted on Soviet agrieulture by Lysenko and those favouring his teaching. Good now crop varieties, some of them outstanding, were produced during the Lys?nko period, but always by the same means that are followed in breeding work elsewhere in the world.

In a final and perceptive chapter tho author asks why it was that Lysenkoist doctrines came to occupy such a powerful position. Ho points out that a wide range of hypotheses will always be current in science and those at the extremities of the range may be fanatical. Such an extreme hypothesis can only be dogmatized in a monopolistic state system. This was aided in the case of Lysenkoism by the tendency to classify ideas as either "bourgeois" or "proletarian", by press censorship, by the isolation of Soviet science from external contacts, by the rigid centralization of scientific administration and education and by the rigidity of control of agricultural policy. The remarkable impression loft by tho book, however, is that in spite of all the difficulties and throughout the length of the episode there were always people who held to their belief in the chromosomal-DNA theory of heredity and were not afraid to voice their beliefs. This culminated in the production and circulation of Medvedev's work which will result, it seems likely, in the exorcism of Lysenko.

The book should be read not only by geneticists but by all concerned with the effects of governmental interference on the advance of science and as an insight into the development and operation of the Soviet system. It is not only a history, it is historic. RALPH RILEY

\section{ALGEBRA OF GENETICS}

\section{Population Genetics}

By W. J. Ewens. (Methuen's Monographs on Applied Probability and Statistics.) Pp. xii + 147. (Methuen: London, February 1969.) $30 s$.

Porulation geneticists, the cynic might conclude, come in two varieties: the biologist who knows little mathematies, and the mathematician who knows little biology. This revicwer, who comes into the first category, found Professor Ewens's book difficult but worthwhile. It is about the algebra of population geneties (not, as its title suggests, about the whole of the subject). It leads the reader gently but firmly from the Hardy-Weinberg law through the darker territories of stochastic processos (discrete, diffuse or branching), over the adaptive topography, to the final attainment of dominance. It is written clearly and elegantly, and takes commendable care to warn us of the important distinction, sometimes the difference, between algebraic model and biological fact.

In his introduction, Ewens states that the book is aimed at the mathematician rather than the geneticist. For the benefit of the former, it is unfortunatoly necesssary to draw attention to some biological errors. The most startling occurs on the first page, where he asserts that "half the $A_{1} A_{1} \times A_{1} A_{2}$ matings will produce $A_{1} A_{1}$ offspring, the other half producing $A_{1} \Lambda_{2}$ "'. Later (pago $10)$, he concludes that heterozygous advantage is a neces. sary and sufficient condition for selective balance. This is untrue if the selective values vary with gene-frequeney, but the qualification is not stated. He perpetuates the superstition that when $\ddot{W}$ (which he calls $W$ ) is equal to one, the size of the population remains constant (page 17). There are also too many typographical mistakes, usually involving the names of plants, animals and people. They give the impression of haste, marring an otherwise well-written book.
Professor E. B. Ford is reported to have defined a specialist as "one who has no elementary knowledge". Alas, it is all too true. We can only hope that some day our prince will come; a mighty polymath who can com. prehend and express clearly the basic principles of both algebra and genctics. Meanwhile, Ewens has given us a useful introduction to some of the thornier aspects of the subject. Bryan Clatke

\section{UNDER THE SPREADING ENTROPY}

Structure and Stability of Biological Macromolecules Edited by Serge N. Timasheff and Gerald D. Fasman. (Biological Macromolecules: a Series of Monographs.) Pp. ix +694 . (Dekker: New York, March 1969.) \$33.50.

Two editors, nine authors and nearly 700 pages of relentless erudition: the book, says the jacket, "is of great value to biochemists, polymer chemists, molecular biologists, biophysicists, biologists, physical chemists, and" (all permutations exhausted, the blurb writer pauses to wipe the foam from his lips) "spectroscopists". The truth is that this book is a collection of extended, often loosely related, essays, and possesses a measure of the ephemeral quality that so often characterizes the genre. The best parts-which justify the book-are those which work over circumscribed areas, not previously reviewed at length, and two chapters in particular will, I think, endure for some time as standard sources.

This is the second of a series of volumes, which Fasman and Timasheff are editing on various aspects, so far almost wholly physical, of biological macromolecules. The first volume, on polyamino-acids, came at a good point in the development of the field and, because of its circumscribed aims, lent itsclf rather better to this type of multi-authored venture. The subject matter of volume two is more diffuse: it ranges from proteins to polysaccharides, from protoin structure in crystals to interaction of salts with macromolecules, and from thermodynamics to infrared spectra. To my mind, the most successful chapters are those by von Hippel and Schleich on the relation of neutral salts to the structure and stability of macromolecules in solution, by Stone on the (to me, at any rate) forbidding subject of polysaccharide conformations and DeVoc's survey of statistical mechanics of polymer conformation. One might have wished, perhaps, that the last of these had set a more leisurcly pace, for it is the shortest and most concentrated in the book and is not a beginner's exposition.

Two chapters on proteins which follow it run between them to more than 220 pages, and if that of DeVoe is ascetic, these are expansive if not self-indulgent. This is no doubt partly a consequence of the subject matter. Since Kauzmann first pointed out some yoars ago the importance of entropy-driven, hydrophobic interactions in stabilizing the structure of globular proteins, the subject has advanced remarkably little in conceptual terms. It is still, for example, impossible to predict from the physical properties of a solvent whether it will be a strong or a wtak denaturant. A copious literature, born perhaps of frustration, has nevertheless grown up, and it is hard now to discern real progress in the physical chemistry of proteins, through the hydrophobic miasma. 'This dearth of hard facts lends a curiously elusive quality to expositions of the generalities of protein conformation, and the chapter by Lurnry and Biltonen is no exception. They offor an individual, often idiosyncratic approach, and have built up an especially elaborate structure concerning the proteins of the chymotrypsinogen group. This is the most provocative and also the most speculative chapter in the book, and rcaders will have to make up their own minds about how many of the concepts are likely to 